\title{
Monetary Policy and the Financial Decisions of Firms - Empirical Study in Vietnam
}

\author{
Assoc. Prof. PHD. Nguyen Thi Hoai Le
}

Vienam Academy of Social Science, 1 Lieu Giai, Hanoi

Email: hoaile74@gmail.com

\section{PHD.Tran Thi Xuan Anh}

Banking Academy, Department of Finance, 12 Chua Boc street, Hanoi

Email: ttxahvnh@gmail.com

\section{Doi:10.5901/mjss.2016.v7n6p27}

\begin{abstract}
In this paper, we present the results from our research on Vietnamese Firms capturing the financial decisions of multiple firms in the transformation of the monetary policy. When the economy is affected by the changes of the monetary policy, the responses of firms differ substantially in terms of location. For example, Da Nang's and Ho Chi Minh's firms were more responsive than Hanoi's firms. As a result, a higher level of monetary-policy sensitivity was witnessed in the output. This research also narrates about specific characteristics, such as sizes, capital structures, and how the monetary policy has altered the financial decisions of firms.
\end{abstract}

Keywords: Monetary policy; financial decisions; financing decision, investment decisions, profit distribution,

\section{Introduction}

Traditional economic models indicate that there is no correlation between the finanical structure of a company and its financial decisions. Therefore, adjusting interest rates or money supply in the economy does not nescessarily bring about the changes in capital structure or cost of capital in business enterprises. This argument was developed from the theory of capital structure in a company by Modilligani \& Miller (1958) which discussed that in the perfect financial market with no information asymmetry between lenders and borrowers; insignificant tax as well as transaction costs, the value of a company is determined as the present value of future cash flows being created from the business operations regardless of which methods of financing being chosen. Nevertheless, these hypotheses could not exist in reality as the financial market is obviously imperfect shown in the information asymetry and the existence of taxes and transaction costs in the market.

Modilligani \& Miller (1963) conducted further study with the objection of the hypothesis about corporate income tax. Accordingly, when companies choose to borrow rather than choose to raise equity fund, they will ultilise the benefits from the so-called "tax shield". This study has been developed into the theory of optimal capital structure which discusses the ways companies use to raise fund through the combination of borrowing capital and owner's equity. The optimal capital structure is the structure in which companies can reach to minimize the cost of capital and thus to maximize the value of the company. The core issue of a company's optimal capital structure is the trade-off between the cost and the benefit that this company has to face with when choosing financing sources (DeAngelo \& Masulis, 1980). Financing through borrowing capital can help companies to generate tax-shield, however, the more companies borrow, the higher probability it will fall into the condition of financial distress, which then will destroy the benefits from tax shield, affect business operations and even lead to the shutdown of the companies. Equity financing can result in the loss of control in companies due to the shared ownership. Also, the fact that shareholders often require a high rate of return meaning that there is more pressure put on the board of management when it comes to equity-funding.

Perking order theory also indicates that the information asymetry affects the investment and financing decisions of each company. Managers of a company often have more advantages than outsiders (common shareholders) do when it comes to the accessibility of information related to business operations. Thus, investors frequently require the higher rate of return, leading to a more expensive cost of capital. Therefore, when a company has a demand for capital, they often firstly call for retained earnings, then debt securities and thus, issuing common stock often comes as the last resort (Mayers and Majluf, 1984). 
The above-mentioned theoretical backgrounds show that in the condition of an imperfect market, the management of monetary policy using the channels of interest rate and credit affects the cost of capital, capital structure of a company and, ultimately, its value. Therefore, the board of manager of each company will have to change a few of fundamental financial decisions in order to maintain and improve the company's value when Central bank adjusts its monetary policy.

However, the effectiveness of the monetary policy is not only reflected by the influence that the policy might have on participants in the market but also by these entities' responses to changes in interest rate and line of credit. In studies about the effect that monetary policy might have on business enterprises, many indicate special characteristics of the examined companies, these features are also the internal problems of the business enterprise system that might affect the ability to absorb the positive changes of monetary policy.

(1) Forms of business organization: Different forms of business enterprises will have a different response upon the changes in monetary conditions, which explains the difference that can be seen in the management of various forms of companies. Specifically, Dewenter and Malalesta (2001) demonstrate that value of private companies is often higher than that of state-owned companies due to higher profitability, higher leverage scale and higher productivity in operations. Tian (2003) shows that the result of business operations of private companies is higher than that of joint-stock companies. More importantly, joint-stock companies often response more sensibly than other forms of business when it comes to changes in macro-economy.

(2) Capital Structure: While determining the optimal capital structure, business enterprises have to face with the Trade-off theory. On the one hand, borrowing will help companies broaden their economic scales and magnify their profit. On the other hand, increasing the level of debts means that companies might have to bare financial distress expenses (including both direct and indirect expenses related to the bankruptcy costs). The trade-off theory leads to the consideration of what financial leverage ratio should be chosen given the existing scale of owner's equity. Generally, companies with limited owner's equity will choose a high financial leverage scale in order to magnify its profit. Moreover, small-scale companies with capital structure tilting towards debt will be more sensible to changes in monetary policy than medium and large-scale ones.

Bernanke and Gertler (1989), Bernanke et al (1998), Carlstrom and Fuerst (1997), Kiyotaki and Moore (1997) demonstrate that internal financial mechanism has a significant influence on companies' response to the shock from monetary policy. An increase in borrowing rate leads to a decrease in companies' profits, leading to a smaller scale of owner's equity in the following period. In the environment of high interest rate risk, companies might have to bare significantly more costs related to borrowing money. If companies choose to continuously raise its financial leverage, they might suffer from the financial distress. The issue of optimal capital structure will not work until each company completely solve the problems in its existing capital structure before being able to fully absorb the financing source from commercial banks.

Zaderey (2003) shows that in Ukraine, A Tight Monetary policy leads to a decrease in companies' stock price and an increase in cost of debt. Companies find it hard to raise funds in the capital market and hence, have to utilize retained earning sources to satisfy the liquidity needs, demand for working capital and other investments.

(3) Ownership Structure: Along with this form of business is the theory of agency cost. Berle and Means (1932) first suggests the hypothesis about agency cost. They find that managers who do not own companies' stocks or own a minority share of companies' stocks and other shareholders will have a conflict in maximizing the value of companies. Specifically, managers are believed to be not interested in the benefits of shareholders, but in their own benefits through compensation packages and other bonuses on the basis of their positions. As a result, these managers tend to borrow less than the expected or optimal amount because this will lower the probability of bankruptcy and more importantly the probability of losing their jobs as well as their own benefits. Hence, ownership structure is considered to have an effect on the behavior of a company when choosing financing sources. (Nguyen Xuan Thang, 2014)

However, according to Jensen and Meckling (1976), costs stemming from the wrong adjustment of company's managers will decrease when their ownership in the company increases. With the increasing level of ownership, managers' benefits will gradually be stick with benefits of other shareholders, and thus, lowering chances that managers will waste companies' resources. In general, market value of a company will go up following an increase in ownership of companies' managers. Thomsen and Pedersen (1996) indicates that there are three scales of ownership in a company. If the largest shareholder own less than $20 \%$ voting share of company's stock then this kind of ownership is said to be dispersed. If the largest shareholder own at least $20 \%$ but less than $50 \%$ of company's voting shares, this form of ownership is considered to be influential. And the final state of ownership is majority ownership with the largest share exceeding $50 \%$ ownership of the company. Financial decisions of a 
company might be distorted by the wrong incentives of managers and these incentives, which often stem from ownership structure, tend to happen in companies with concentrated ownership (Demsetz (1983), Shleifer and Vishny (1986), Agrawal and Mandelker (1990)). In other words, in companies with dispersed ownership, monetary policy will have a more effective impact on financial decisions of managers.

(4) Economies of scale: Some practical experiments on behaviors of companies in making financial decisions conclude that there is a significant difference between responses of small-scale companies and large-scale companies (classified by 3 factors: revenues, total assets and total labor - Cihan Yalcin, Sprios Bougheas and Paul Mizen (2002)) upon the shock from macro-economy.

Fazzari, Hubbard and Petersen (1988) discusses that small-scale companies have a higher rate of returns, pay out cash dividends less than large-scale ones, borrow money and invest more than the big business enterprises. Gertler and Gilchrist (1994), Fernardo N.de Oliveira (2009) that investigate responses of companies with various scales (by total assets) upon changes by monetary policy (proxied by interest rate in the open market - Bernanke and Blinder (1992), Fernardo (2009)) show that small companies are more sensible than large ones because the small ones have little opportunities to get access into financial markets to find other alternative means of financing other than commercial bank's loan. These finding are totally in line with what has been found in Cihan Yalcin, Sprios Bougheas và Paul Mizen (2002).

Thomas F.Cooley and Vincenzo Quadrini (1999) implements the study about the relationship between monetary policy and companies' financial decisions. This study also suggested that when there is a shock in the macro-economy as Central Bank follows a tight monetary policy, small-scale companies tend to borrow more money (real debt) and thus, having a more fluctuated level of output compared with large-scale ones. Gertler and Gilchrist (1994) reaches the same conclusion.

Elliehausen and Wolken (1990) indicates that small-scale companies are those who get a strong influence from a tight monetary policy as their revenues decreases due to the lack of diversity in business operations. As such, inventory also has to be adjusted downward, leading to a smaller scope of operations and a smaller ratio of debt in capital structure.

Moreover, Chu Khanh Lan (2014) studying about transmission channels concludes that when Central Bank implements a tight monetary policy, small enterprises with the fundamental capital source coming from commercial bank's loan will suffer from the shortage of fund while larger ones can get access to other nonbank financing source.

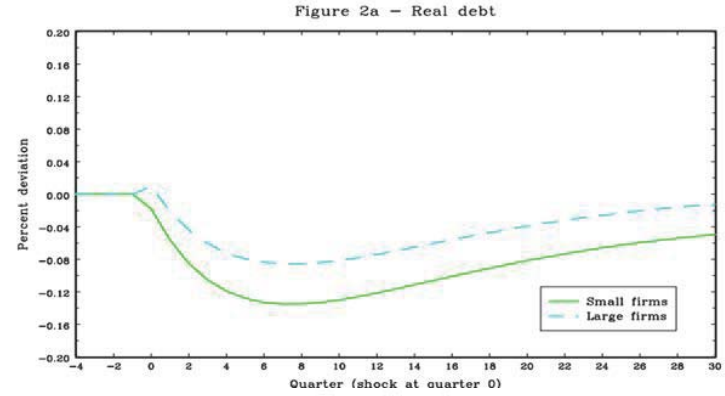

Figure 2b - Output

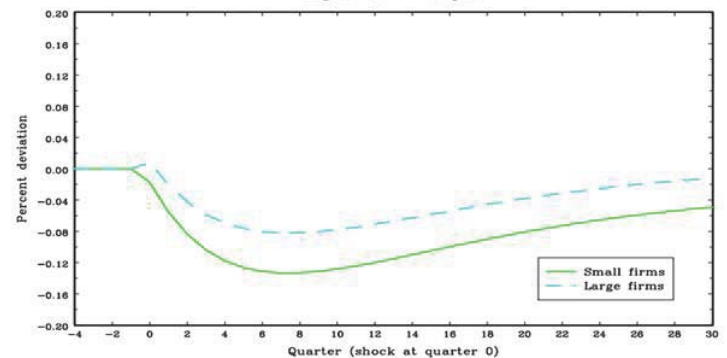

Figure 1. Responses of companies of various scales upon the monetary shock.

Source: "Monetary Policy and Financial Decisions of Business Enterprises" Thomas F. Cooley and Vincenzo Quadrini (1999) 
Furthermore, banks also tend to adjust the credit flows from small-scale companies' loan to large-scale ones' loan in the context of a tight monetary policy. This, in other words, is the filtering process in order to find high quality customers. Lang and Nakamura (1995) conveys the same finding. Bernanke, Gertler, and Gilchrist (1996) demonstrates characteristics of business enterprises that might affect the amount of credit supplied by their commercial banks. In the context of tightening the monetary condition, small companies with increasing level of agency cost have more difficulties in accessing various sources of financing than large companies do. With the sample of companies in manufacturing sector, Bernanke et al (1996) finds that small companies tend to reduce debts when large ones do the opposite.

Some studies include both characteristics of accessibility to various sources of financing and balance sheets in their analyses. Kashyap, Lamont and Stein (1994) finds that companies that significantly depend on commercial banks' loan will suffer from a stronger fluctuation in inventories than companies with diversified sources of financing. Similarly, Gertler and Gilchrist (1994) also reaches the same conclusion that small-sized companies decrease borrowing while large-sized ones increase debts when State Bank implement a tight monetary policy. Tightening monetary policy makes large-size companies increase their current debts that need to satisfy demands for working capital. Small-sized companies, however, do not have enough conditions to borrow in a short-term basis and thus, inventories go down during these time.

Regarding customers' financial status, Gertler and Gilchrist (1993) indicates that small companies tend to reduce inventories and short-term borrowing. In contrast, large companies do not have these kinds of reactions, which means that large companies do not have to face with liquidity issues like small-sized companies. Friedman and Kuttner (1993) also reports the same finding.

(5) Other factors: Besides above-discussed internal issues in business enterprises, there are other characteristics that might have an influence on the effectiveness of monetary policy such as the size of assets used as collaterals in commercial banks' loan agreement, companies' credit rating, their ages (Cihan Yalcin, Sprios Bougheas and Paul Mizen (2002)). Particularly, older companies with higher credit scores may find it easier to get access to other alternative means of financing compared to young companies (Diamond $(1984,1991)$ and Chant (1992)).

In this paper we argue that many differences in behavior of firm's size and form of its business have common explanations. It is that financial decisions of firms will differ systematically with its size measured by the amount of equity in the firm (capital structure); business type measured in form of limited companies and jointstock companies. The higher debt - equity ratios firms tend to have more sensitivity with monetary policy. Limited firms have higher flexible capital structure, thus producing more reactions to monetary policy.

\section{Empirical Study in Vietnam}

\subsection{Data sample}

We conducted a survey of 500 companies operating in Hanoi, Ho Chi Minh City, and Da Nang, and then the company system in Vietnam is observed and examined based on following criteria: type of business, capital structure, size of company (labour, assets and equity size), as well as the adjustment of financing decisions before the changes of monetary policy. The surveys were sent directly to the directors to assess three above-mentioned theories. 491 surveys were accepted and 23 were excluded due to excess of information

Regarding types of business: the surveyed results show that, above $52 \%$ of companies operating in 3 cities are limited-liability companies consisting of two or more members, 35\% are joint stock companies and the rest are other types of business. However, these figures are different among cities. To illustrate,

- The data sample in Hanoi showed that joint stock companies occupy a large part with the proportion of $55.37 \%$. Secondly, limited liability companies consisting of 2 or more members occupy $33.17 \%$ and $6.61 \%$ are other types of business.

- The data sample in Ho Chi Minh City showed that, limited-liability companies occupy a large part with the proportion of $69.23 \%$, while joint stock companies have the proportion of $20.19 \%$, and other types of business account for $10.57 \%$

- The data sample in Da Nang showed that limited-liability companies occupy a large part with the proportion of $48.24 \%$, joint stock companies have the proportion of $24.56 \%$, and other types of business take $21.05 \%$. 
Table 1. Structure of companies in Hanoi, Ho Chi Minh City, Da Nang

\begin{tabular}{|l|c|c|c|}
\hline Type of businesses & Limited liability companies & Joint stock companies & Other types of businesses \\
\hline Average & $50.21 \%$ & $33.37 \%$ & $12.74 \%$ \\
\hline Hanoi & $33.17 \%$ & $55.37 \%$ & $6.61 \%$ \\
\hline Ho Chi Minh City & $69.23 \%$ & $20.19 \%$ & $10.57 \%$ \\
\hline Da Nang & $48.24 \%$ & $24.56 \%$ & $21.05 \%$ \\
\hline
\end{tabular}

Source: Results of the researchers

Conducting the survey of capital structure based on 500 companies in 2 cities, regarding funding resources, $71.33 \%$ companies mobilize their finance from the owners, and $37.38 \%$ companies mobilize their finance from commercial loan (non-preferential). Regarding the proportion of debts to total capital, $52.67 \%$ companies remain the percentage of debts below $10 \%, 31.11 \%$ companies choose this figure from $10 \%$ to $20 \%$. Regarding the proportion of bank loans to total debt, $74.67 \%$ companies maintain the percentage of bank loans (non-preferential) below $10 \%$. Regarding the proportion of short-term debt to total debts, almost $80 \%$ companies decide the percentage of short-term debts to total debt below $20 \%$.

\subsection{Research questions}

Based on this data sample, the survey questions focus on 3 hypotheses:

$H_{0}$ : Financing decision (capital mobilizing) of companies is affected by monetary policy.

$H_{1}$ : Investment decision of companies is affected by monetary policy.

$\mathrm{H}_{2}$ : Profit distribution decision is affected by monetary policy.

Specifically, financing decision of companies is determined by the proportion of debts and liabilities to equity and the proportion of debts and liabilities to total asset; investment is explained by the scope of total assets and annual added value; profit distribution decision is illustrated by EPS (earnings per share0) and DPS (dividend per share). The management of monetary policy is explained by the movement in monetary conditions of interest rate and credit limitation.

\subsection{Methodology}

The questions were constructed by criteria suggested by $\mathrm{VCCl}$ (2008). The conduct of monetary policy for company system in Vietnam is evaluated based on three important decisions: financing decision, investment decision, and profit distribution decision mentioned above. However, the levels of impact of monetary policy on companies are different due to some internal characteristics of companies. These factors also affect the absorption of monetary policy through financing decisions of companies in the data sample. Therefore, the variables, such as types of business, capital structure, size of companies are chosen to analyze the efficiency of monetary policy under the aspect of absorption capacity of companies in Vietnam.

- Financing decision: companies point out their expected interest rate on the basis of current economic environment, and research group put them in the place of considering which sources would be more appropriate if the interest rate is higher than expected. Survey Results then are grouped into 2 groups based on the forms of business organization since Joint stock companies (JSC) tend to act differently compared to limited liability companies (LLC) when it comes to financing-decision making. The same practice is applied to 3 different geographical areas: Ho Chi Minh City, Hanoi and Da Nang.

- Investment decision: We place all companies in the case of interest rate rising high and then following the down-ward trend. In each scenario, we examine the impact that increasing or decreasing interest rate environment might have on investment decision of the companies. Again, we apply the same act to all the cities: Ho Chi Minh City, Hanoi and Da Nang.

- Profit Distribution decision: Research group tests whether monetary policy has an effect on profitability and profit distribution decision of all companies and these companies are examined separately in 2 distinctive groups: Joint stock companies and Limited Liabilities Companies to see the difference in the level of impact. The same practice is applied to all the areas from Hanoi, Ho Chi Minh City to Da Nang. 


\section{Empirical Results}

\subsection{Financing decisions response to monetary policy}

Companies surveyed in Hanoi, Da Nang, and Ho Chi Minh City belongs to different types of business. In this part, the paper focuses on two groups of business occupying the largest part in the data sample: joint stock companies (JSC) and limited-liability companies (LLC). Joint stock companies and limited liability companies have differences in characteristics, and the tendency of exposure to monetary policy.

Regarding financing decisions, the responses to the interest rate of joint stock companies are dissimilar to those of limited liability companies. It can be seen from Figure 3 that there exists the difference in the impact of the interest rate between joint stock companies and limited liability companies in Hanoi. With respect to joint stock companies, when interest rate is higher than the expected level, the options to issue shares or to use other finances remain stable, whereas, bank loans declines in terms of priority and retained earnings increases. Regarding the limited liability companies, when the interest rate is in disadvantageous condition, the financing resources from the owners and others, along with bank loans, increase in terms of the level of priority while retained earnings decrease.

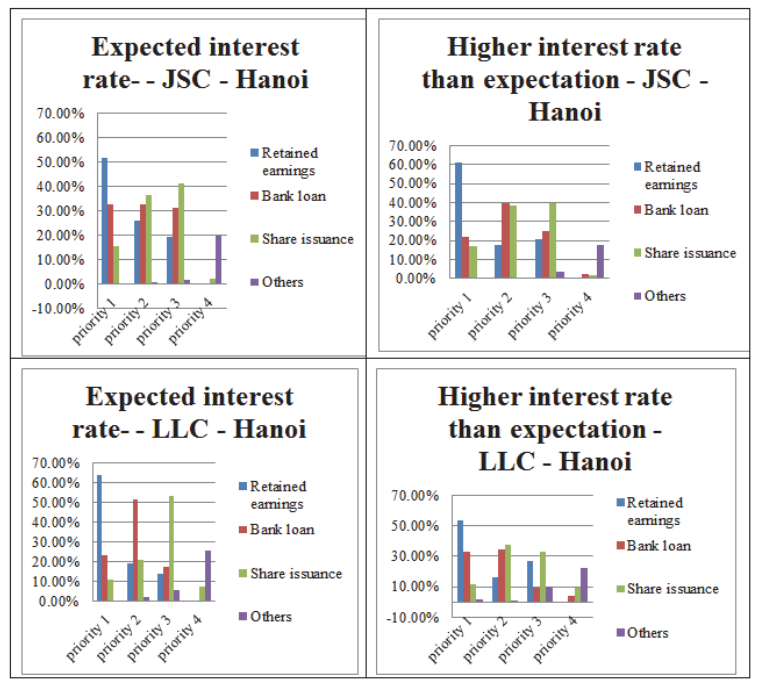

Figure 2. Financing decision of joint stock companies and limited liability companies in Hanoi Source: Survey Results of Research Group

However, the differences in the interest rate movement between joint stock companies and limited liability companies observed in Da Nang and Ho chi Minh are insignificant (Figure 3\&4). When the interest rate is higher than the expected level, both joint stock companies and limited liability companies have the tendency of emphasizing the internal resources of capital such as retained earnings and resources from issuing shares, or from the owners; and restricting the commercial bank loans. Limited liability companies tend to increase the level of employing other resources of capital (for example, trade credit) in case that the interest rate is higher than the expected level. 


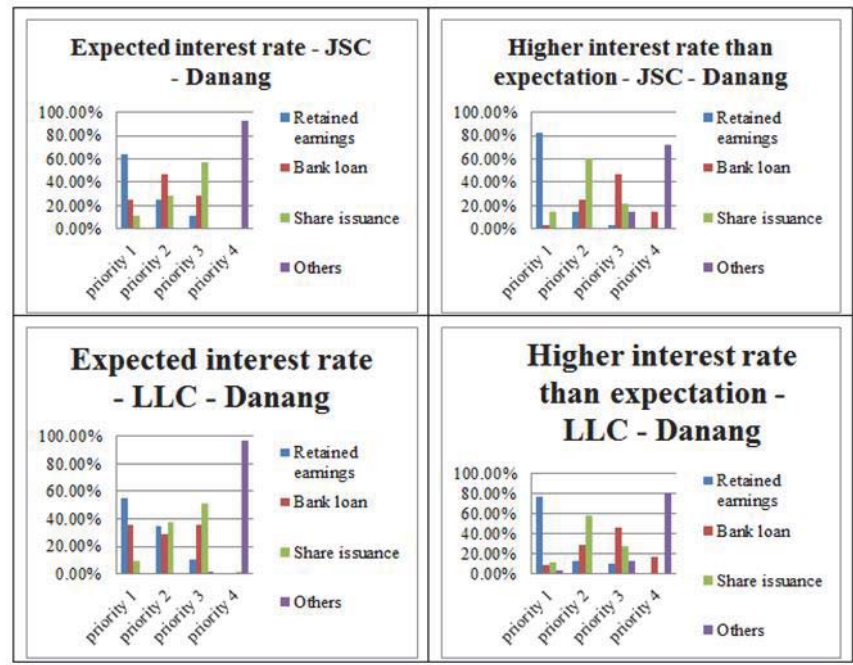

Figure 3. Financing decision of joint stock companies and limited liability companies in Da Nang Source: Survey Results of Research Group

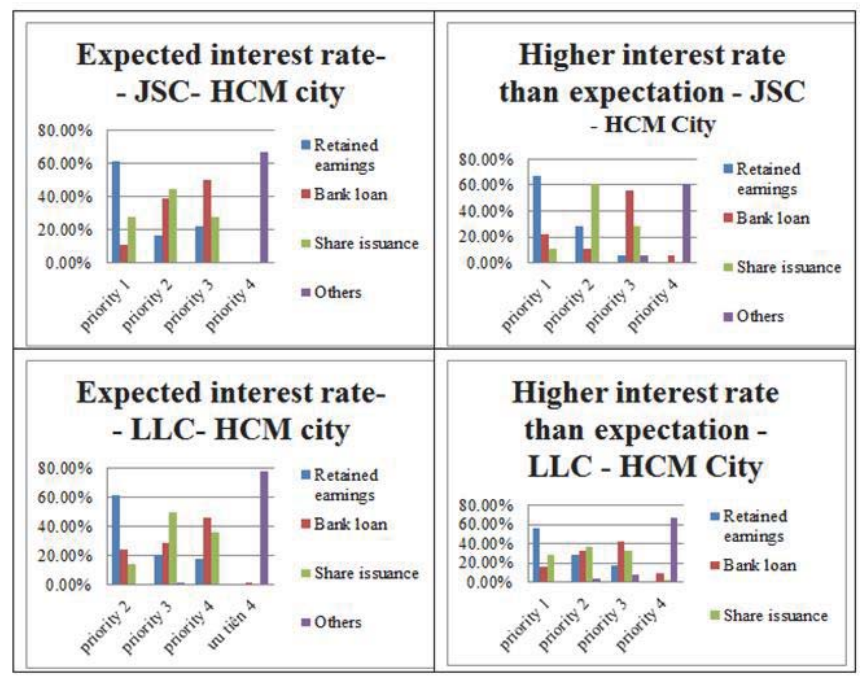

Figure 4. Financing decision of joint stock companies and limited liability companies in Ho Chi Minh City Source: Survey Results of Research Group

\subsection{Investment decisions response to monetary policy}

In terms of investment decision, those Companies of various types of business have different choices of employing the financing resources for long-term investment.

Companies in Hanoi: When the interest rate decreases, joint stock companies observed in Hanoi tend to reduce their usage of internal resources of capital and increase the short and long-term debts, along with other resources and vice versa. Meanwhile, limited liability companies use other financing resources when the interest rate is in the beneficial condition and reduce the remaining resources of capital to finance their long-term investment. 


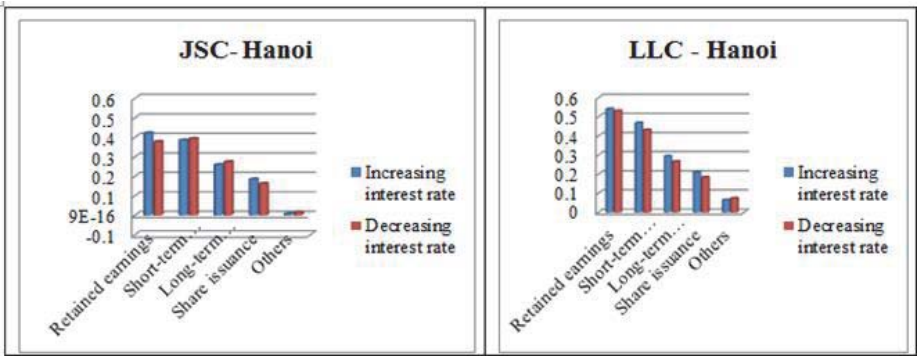

Figure 5. Long-term financing resources of Companies in Hanoi

Source: Survey Results of Research Group

Companies in Da Nang: Joint stock companies and limited liability companies in Da Nang tend to be influenced by the long-term investment decisions in the same way. The only difference is the level of alteration in the long-term financing resources. In addition, joint stock companies observed in Da Nang do not use other resources of capital even though the interest rate from monetary policy fluctuates favorably or unfavorably while limited liability companies maintain the level of using other resources of capital to finance the long-term investments in both cases.

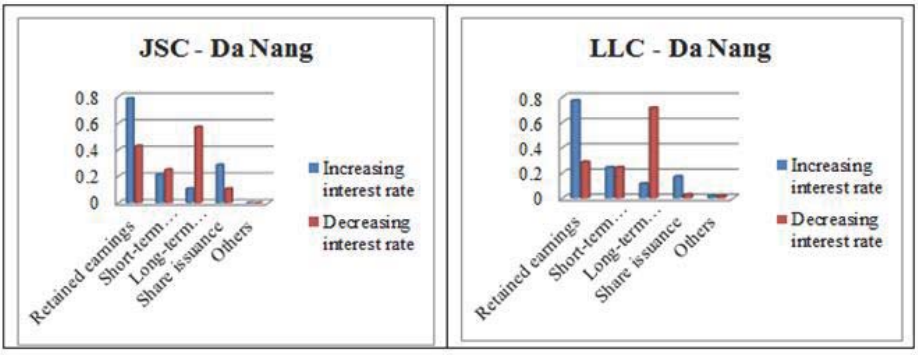

Figure 6. Long-term financing resources of Companies in Da Nang

Source: Survey Results of Research Group

Companies in Ho Chi Minh City: When the interest rate is at the expected level, joint stock companies observed in Ho Chi Minh City tend to use the internal resources of capital (retained earnings and issuance of shares) more than that of limited liability companies focusing on the usage of retained earnings and commercial bank loans. When the interest rate is higher than the expected level, joint stock companies increase their priority in employing retained earnings, commercial bank loans and reducing the issuance of shares. Limited liability companies tend to reduce their priority in using their retained earnings, lessen their bank debts and expand resources of capital from the owners to finance their business operations.

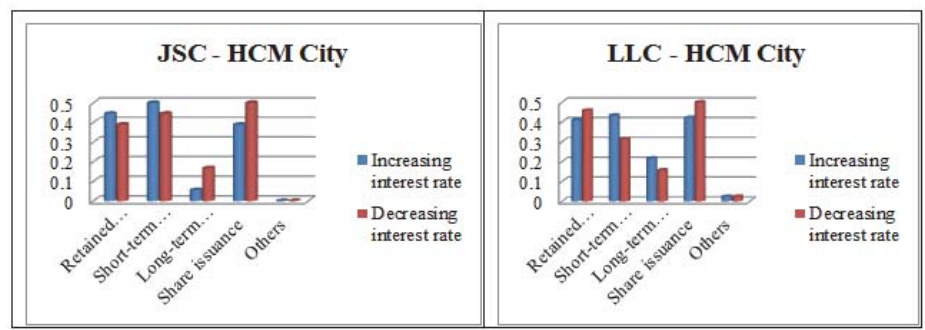

Figure 7. Long-term financing resources of Companies in Ho Chi Minh City

Source: Survey Results of Research Group 
When the movement of the interest rate follows an adverse trend, joint stock companies and limited liability companies observed in Ho Chi Minh City finance their long-term investments mainly by short-term debts, retained earnings, issuance of shares or capital from the owners. Since the interest rate declines, joint stock companies reduce their resources of finance from retained earnings and short-term debts while increase their long-term debts and issuance of shares in terms of investment activities. Joint stock companies do not employ other capitals for their investments. Limited liability companies extend their usage of internal capital (retained earnings and the resources from their owners), lessens both long-term and short-term debts, while remain the level of other capitals.

\subsection{Profit distribution decision response to monetary policy}

In terms of profit distribution decision, the impacts of monetary policy on joint stock companies and limited liability companies are different in each observed location.

Companies in Hanoi: The results observed between two types of business in Hanoi - joint stock companies and limited liability companies indicate that there exists the dissimilarity in the evaluation of the influence of monetary policy on their profit distribution decisions. However, the levels of difference also vary among indicators used to research, for instance, the proxy of the profitability (indicator: ROE), the proxy of profit distribution method (indicator: dividend and profit distribution), the proxy of survey (from "no impact" to "significant impact").

Table 2. The impact of monetary policy on the profit distribution decision of Companies in Hanoi

\begin{tabular}{|c|c|c|c|c|c|c|c|c|c|}
\hline Location & Type of business & Profitabi-lity & $\begin{array}{l}\text { No } \\
\text { impact }\end{array}$ & $\begin{array}{l}\text { Insigni-ficant } \\
\text { impact }\end{array}$ & $\begin{array}{l}\text { Low imp- } \\
\text { act }\end{array}$ & $\begin{array}{l}\text { Aver-age } \\
\text { impa-ct }\end{array}$ & $\begin{array}{l}\text { Relati-vely } \\
\text { high impact }\end{array}$ & \begin{tabular}{|l|} 
High \\
impa-ct
\end{tabular} & $\begin{array}{l}\text { Extre-mely } \\
\text { high impact }\end{array}$ \\
\hline \multirow{4}{*}{ Hanoi } & \multirow[t]{2}{*}{ Joint stock companies } & $R O E$ & $8.15 \%$ & $23.70 \%$ & $22.96 \%$ & $20.74 \%$ & $16.30 \%$ & $2.96 \%$ & $0.74 \%$ \\
\hline & & Dividend & $10.37 \%$ & $23.70 \%$ & $10.37 \%$ & $19.26 \%$ & $15.56 \%$ & $11.11 \%$ & $2.96 \%$ \\
\hline & \multirow[t]{2}{*}{ Limited liability companies } & ROE & $5.50 \%$ & $29.36 \%$ & $20.18 \%$ & $19.27 \%$ & $19.27 \%$ & $4.59 \%$ & $0.00 \%$ \\
\hline & & Profit distribut-ion & $8.26 \%$ & $23.85 \%$ & $6.42 \%$ & $29.36 \%$ & $9.17 \%$ & $5.50 \%$ & $0.92 \%$ \\
\hline
\end{tabular}

Source: The survey results of the researchers

For ROE, as it can be seen, the impacts on limited liability companies are more significant than that of joint stock companies (Table 2). For example, when researching the influences of monetary policy on ROE, $20 \%$ of joint stock companies showed that these influences ranging from "relatively high" to "extremely high" while this figure for limited liability companies is higher with $23.86 \%$.

Table 3. The impact of monetary policy on the profit distribution decision of companies

\begin{tabular}{|l|l|c|c|c|}
\hline \multicolumn{2}{|c|}{} & Hanoi & Da Nang & Ho Chi Minh City \\
\hline Joint stock companies & \multirow{2}{*}{ ROE } & $20.00 \%$ & $17.85 \%$ & $5.56 \%$ \\
\cline { 3 - 5 } Limited liability companies & & $23.86 \%$ & $25.72 \%$ & $9.63 \%$ \\
\hline \hline Joint stock companies & Dividend & $29.63 \%$ & $25.00 \%$ & $16.67 \%$ \\
\hline Limited liability companies & Distributed profit & $15.59 \%$ & $1.43 \%$ & $20.48 \%$ \\
\hline
\end{tabular}

Source: The survey results of the researchers

It is reasonable that joint stock companies respond more sensitively compared to limited liability companies in terms of changes of monetary policy because this type of business can approach various resources of finance more quickly than limited liability companies do. Moreover, in previous analyses, the capital formed by debt of limited liability companies in Hanoi is higher than that of joint stock companies; therefore, when the amended monetary policy is implemented, the impact on limited liability companies is greater than joint stock companies. In general, this leads to the fact that the efficiency of business operation and the profit of limited liability companies in Hanoi is relatively affected compared to joint stock companies.

In terms of proxies for dividend - joint stock companies and profit distribution - limited liability companies, according to table 3 , the proportion of companies that evaluated "relatively high" to "extremely high" impacts of monetary policy on these types of business are $29.63 \%$ and $0.92 \%$ respectively. Thus, it can be seen that when the monetary policy changes, the profit distribution policy of joint stock companies is affected more significantly than that of limited 
liability companies. This evaluated results, as well as the previous survey results of the change in financing decisions before the movement of monetary policy, indicated that joint stock companies in Hanoi tend to adjust their profit distribution policy corresponding to the monetary policy's movement. For instance, these companies will reduce dividend payments, increase retained earnings used in their business while lessen their bank loans as the interest rate goes up because of the tightened monetary policy. On the contrary, the effects of monetary policy on the profit distribution policy of limited liability companies is extremely insignificant since limited liability companies have a low level of sensibility in mobilizing other capitals from debt or equity. Therefore, when there is a movement in the monetary policy, these companies are mostly dependent on debt instead of depending on reduction of profit distribution to their owners and increase in the retained earnings.

Similar to the survey conducted for joint stock companies and limited liability companies in Hanoi, the impact of monetary policy on the chosen indicators of different types of business in Da Nang and Ho Chi Minh City indicated that: (i) the impact level of monetary policy on ROE of limited liability companies is higher than that of joint stock companies; (ii) the impact level of monetary policy on profit distribution policy (reflected by dividend indicator and profit distribution) of limited liability companies is lower than that of joint stock companies. Specifically:

Companies in Da Nang: According to table 3,17.85\% of joint stock companies in Da Nang view that the impact of monetary policy on their ROE is from "relatively high" to "extremely high" level and $25.72 \%$ limited liability companies showed their evaluation for this range when they are surveyed.

Table 4. The impact of monetary policy on the profit distribution decision of companies in Da Nang

\begin{tabular}{|c|c|c|c|c|c|c|c|c|c|}
\hline Locat-ion & Type of business & Profitability & $\begin{array}{l}\text { No } \\
\text { impact }\end{array}$ & \begin{tabular}{|l|} 
Insignif-icant \\
impact
\end{tabular} & $\begin{array}{l}\text { Low } \\
\text { impact }\end{array}$ & $\begin{array}{l}\text { Avera-ge } \\
\text { impact }\end{array}$ & $\begin{array}{l}\text { Relati-vely } \\
\text { high impact }\end{array}$ & $\begin{array}{l}\text { High } \\
\text { impact }\end{array}$ & $\begin{array}{l}\text { Extre-mely } \\
\text { high impact }\end{array}$ \\
\hline \multirow{4}{*}{ Da Nang } & \multirow[t]{2}{*}{ Joint stock companies } & ROE & $7.14 \%$ & $17.86 \%$ & $25.00 \%$ & $21.43 \%$ & $10.71 \%$ & $3.57 \%$ & \begin{tabular}{|l|}
$3.57 \%$ \\
\end{tabular} \\
\hline & & Dividend & $7.14 \%$ & $28.57 \%$ & $25.00 \%$ & $14.29 \%$ & $7.14 \%$ & $3.57 \%$ & $14.29 \%$ \\
\hline & \multirow{2}{*}{$\begin{array}{l}\text { Limited liability } \\
\text { companies }\end{array}$} & $R O E$ & $14.29 \%$ & $32.86 \%$ & $14.29 \%$ & $12.86 \%$ & $22.86 \%$ & $2.86 \%$ & $0.00 \%$ \\
\hline & & Profit distribut-ion & $30.00 \%$ & $37.14 \%$ & $14.29 \%$ & $10.00 \%$ & $1.43 \%$ & $0.00 \%$ & $0.00 \%$ \\
\hline
\end{tabular}

Source: The surveys' results of the researchers

Regarding the proxies of dividend (joint stock companies) and profit distribution (limited liability companies), 25\% of joint stock companies claimed that the impact of monetary policy on their dividend policy or profit distribution policy ranges from "relatively high" to "extremely high" level, meanwhile, this level of impact is witnessed at $1.43 \%$ of limited liability companies in the observed sample. In other words, not being controlled by monetary policy, profit distribution policy of most limited liability companies remains relatively stable in terms of distributing the profit to the owners and retained earnings in order to finance their business activities. This result can be shown when comparing the figures from "relatively high" to "extremely high" level in Hanoi (15.59\%), Ho Chi Minh City (20.48\%) and Da Nang (1.43\%). However, this may be a disadvantage for limited liability companies in these locations when monetary policy's movement follows an unfavorable trend. For example, if interest rate increases, that the profit distribution policy remains unchanged will lead to the reduction of business or the increase in the bank loans and other financing resources, followed by the erosion of the profit after tax through borrowing costs.

Companies in Ho Chi Minh City: Based on the surveyed results for two major types of business in Ho Chi Minh City, $5.56 \%$ of joint stock companies and $9.63 \%$ of limited liability companies claimed that the impact of monetary policy on ROE is from "relatively high" to "extremely high". Meanwhile, these figures for the proxy of profit distribution policy (dividend - joint stock companies and profit distribution - limited liability companies) of joint stock companies and limited liability companies are $16.67 \%$ and $20.48 \%$ relatively.

Table 5. The impact of monetary policy on the profit distribution decision of companies in Ho Chi Minh City

\begin{tabular}{|c|c|c|c|c|c|c|c|c|c|}
\hline Location & Type of business & Profitabili-ty & \begin{tabular}{|l|} 
No \\
impact
\end{tabular} & $\begin{array}{l}\text { Insignif-icant } \\
\text { impact }\end{array}$ & $\begin{array}{l}\text { Low } \\
\text { impact }\end{array}$ & $\begin{array}{l}\text { Aver-age } \\
\text { impact }\end{array}$ & $\begin{array}{l}\text { Relat-ively } \\
\text { high impact }\end{array}$ & \begin{tabular}{|l} 
High \\
impact
\end{tabular} & \begin{tabular}{|l} 
Extr-emely \\
high impact
\end{tabular} \\
\hline \multirow{4}{*}{ Ho Chi Minh City } & \multirow[t]{2}{*}{ Joint stock companies } & ROE & $33.33 \%$ & $44.44 \%$ & $11.11 \%$ & $5.56 \%$ & $0.00 \%$ & $5.56 \%$ & $0.00 \%$ \\
\hline & & Dividend & $33.33 \%$ & $16.67 \%$ & $27.78 \%$ & $5.56 \%$ & $5.56 \%$ & $11.11 \%$ & $0.00 \%$ \\
\hline & \multirow[t]{2}{*}{ Limited liability companies } & ROE & $25.30 \%$ & $34.94 \%$ & $16.87 \%$ & $13.25 \%$ & $6.02 \%$ & $3.61 \%$ & $0.00 \%$ \\
\hline & & \begin{tabular}{|l|} 
Profit distribution \\
\end{tabular} & $24.10 \%$ & $37.35 \%$ & $9.64 \%$ & $8.43 \%$ & $14.46 \%$ & $6.02 \%$ & $0.00 \%$ \\
\hline
\end{tabular}

Source: The surveys' results of the researchers 
The surveyed results show that the proportions of joint stock companies and limited liability companies which evaluated the impact level of monetary policy on ROE in Ho Chi Minh City (5.56\% and 9.63\%) are lower than those of Hanoi (20\% and $23.86 \%$ ) and $\mathrm{Da}$ Nang (17.85\% and $25.72 \%)$. This obvious difference is originated from the fact that only a small percentage of companies in Ho Chi Minh City (below 10\%) compared with those of other locations (above 20\%) employs bank loans with the level being $20 \%$ of total capital structure. Besides, most companies in Ho Chi Minh City set bank loans at the third and fourth place in priority when the movement of monetary policy follows the unfavorable trends, after the financing resources from retained earnings (reflected by a relatively high impact level of monetary policy on dividend policy and profit distribution policy and issuing share policy).

\section{Conclusions}

Although the level was not significant, monetary policy has had certain influences on the business activities of companies under different aspects in the research, shown through three main decisions - financing decision, investment decision, and profit distribution decision.

Firstly, regarding financing decisions, according to the surveyed results in Hanoi, Da Nang, Ho Chi Minh City, although debt does not occupy a large proportion of operating companies, it plays an important role as one of three main financing resources (along with retained earnings and owners' fund) and a channel that obviously expresses the impact of monetary policy on companies. With the effect of monetary policy leading to a higher borrowing interest rate, companies observed in three locations have had tendency to reduce their commercial bank loans, increase in using their internal capitals like retained earnings, issuance of shares or owners' fund, and other capitals.

Secondly, in terms of investment decisions, the change in monetary policy - interest rate affected the borrowing costs, the costs of capital, and the profitability ratio of companies. After that, companies have adjusted their investment behaviors and responded the movement of monetary policy in order to enhance their investment efficiency. Monetary policy had different influences on the companies in three locations and the levels of transmission to the companies in $\mathrm{Da}$ Nang and Ho Chi Minh City are higher than that in Hanoi. When surveying those companies, a higher level of sensitivity was witnessed in changing the investment decision, together with changing the financing resources for investments as the interest rate fluctuated. The interest rate changed, companies in Da Nang adjusted their capital structure to increase their borrowing fund when interest rate decreased and vice versa, and thus affected the cost of capital and investment decision. Whereas, companies in Ho Chi Minh City, depending insignificantly on the borrowing funds, obtained the transmission of monetary policy through considering the change of the market and investment policy, unlike companies in Da Nang who considers through the cost of capital. To be specific, the decreasing interest rate stimulated the market demand of consumption, increased the net value of assets, etc., companies expanded their business and increase their long-term investment with taking advantages of owner's equity and retained earnings instead of increasing bank loans.

Thirdly, the evaluation of companies showed that monetary policy affected profit distribution policy although only $22 \%$ of surveyed companies claimed that the impact of monetary policy was from "relatively high" to "extremely high" while mostly $70 \%$ of companies stated that the impact remained at low or insignificant level. The change in monetary policy affected the financing decision and investment decision, affecting the efficiency of business activities and profit distribution policy of companies.

\section{References}

A. Agrawal and G. N. Mandelker (1990), Large Shareholders and the Monitoring of Managers: The Case of Anti-takeover Charter Amendments, Journal of Financial and Quantitative Analysis, June 1990, V. 25(2), pp. 143-161

Adolf Berle and Gardiner Means (1932), The Modern Corporation and Private Property, Transaction Publishers.

Ando, Albert, and Franco Modigliani (1963), The 'Life Cycle' hypothesis of Saving: Aggregate Implications and Tests, American Economic Review, vol. 53 (March 1963), pp. 55-84

Andrei Shleifer and Robert W. Vishny (1986), Large Shareholders and Corporate Control, The Journal of Political Economy, Volume 94 , Issue 3, Part 1, 461-488.

Anil K. Kashyap; Owen A. Lamont and Jeremy C. Stein (1994), Credit Conditions and the Cyclical Behavior of Inventories, The Quarterly Journal of Economics, Volume 109, Issue 3, 565-592

Anil K. Kashyap; Owen A. Lamont; Jeremy C. Stein.(1994), The Quarterly Journal of Economics, Volume 109, Issue 3 (Aug., 1994), 565-592

Ben Bernanke and Mark Gertler, (1989), Agency Costs, Net Worth, and Business Fluctuations, The American Economic Review, Vol. 79, No. 1 (Mar., 1989), pp. 14-31

Ben Bernanke; Mark Gertler; Simon Gilchrist (1996), The Financial Accelerator and the Flight to Quality, The Review of Economics and 
Statistics, Vol. 78, No. 1. (Feb., 1996), pp. 1-15.

Benjamin M. Friedman \& Kenneth N. Kuttner, (1993), Economic Activity and the Short-term Credit Markets: An Analysis of Prices and Quantities, Brookings Papers on Economic Activity, Economic Studies Program, The Brookings Institution, vol. 24(2), pages 193284

Bernanke, B. \& Gertler, M. \& Gilchrist, S., (1998), The Financial Accelerator in a Quantitative Business Cycle Framework, Working Papers 98-03, C.V. Starr Center for Applied Economics, New York University.

Bernanke, B. and Gertler, M., (1995), Inside the black box: The credit channel of monetary policy transmission, Journal of Economic Perspective, Vol. 9 , pp. 27-48

Bernanke, B.S., and A.S. Blinder (1988), Credit, money, and aggregate demand, American Economic Review, vol. 78, no. 2, 435-439

Bernanke, B.S., and A.S. Blinder (1992), The Federal Funds Rate and the Channels of Monetary Transmission, The American Economic review, vol. 82, issue 4, pages $901-21$

Blinder, A.S. and Maccini, L. J., (1991), Taking stock: A critical assessment of recent research on inventories, Journal of Economic Perspectives, Vol. 5, pp. 73-96

Boldin, M., (1994), Econometric analysis of the recent downturn in housing: Was it a credit crunch?, Federal Reserve Bank of New York.

Bucru Aydin \& Engin Volkan (2011), Incorporating Financial Stability in Inflation Targeting Frameworks, IMF Working paper

Charles T Carlstrom, Timothy S Fuerst, (1997), Agency costs,net worth, and business fluctuations: A computable general equilibrium analysis, The American Economic review, 893-910.

Chatelain, Jean-Bernard \& Generale, Andrea \& Hernando, Ignacio \& Von Kalckreuth, Ulf \& Vermeulen, Philip, (2001), Firm investment and monetary transmission in the euro area, Working Paper Series 0112, European Central Bank.

Chirinko, R., (1993), Business fixed investment spending: A critical survey of modeling strategies, empirical results, and policy implications, Journal of Economic Literature, Vol. 31, pp. 1875-1911

Chu Khanh Lan (2014), Working paper: Monetary policy transimition in Vietnam, Banking Academy

Cihan Yalcin, Spiros Bougheas and Paul Mizen (2002), Corporate Credit and Monetary Policy: The Impact of Firm-Specific Characteristics on Financial Structure, Discussion Papers in Economics, No. 02/15, University of Nottingham

Cihan Yalcin, Spiros Bougheas and Paul Mizen, (2002), Corporate credit and monetary policy : the impact of firm-specific characteristics on financial structure, Working Paper

Cooley, Thomas F., and Vincenzo Quadrini, (1999), Financial Markets and Firm Dynamics, Working paper Duke University.

Dao Le Minh (2002), "Dividend policy and its impact on enterprises - implications for Vietnam", working paper, Securities and Exchange of Vietnam Commission.

Demsetz, Harold (1983), The Structure of Ownership and the Theory of the Firm. J. Law and Econ. 26: 375-90.

Douglas W Diamond (1984), Financial Intermediation and Delegated Monitoring, The Review of Economic Studies

Douglas W Diamond (1991), Monitoring and Reputation: The choice between bank loans and directly placed debt, Journal of Political Economy, 689-721

Fazzari, Steven M., R. Glenn Hubbard, and Bruce C. Petersen (1988), Financing Constraints and Corporate Investment, From Brookings Papers on Economic Activity, Vol. 1, pp. 141-195.

Feinberg and Robert, M., 2000, The Role of International Discipline in Three Developing Economies: Exchange Rate Effects on Domestic Prices in Colombia, Korea and Morocco, Review of International Economies, 8, pp.126-133.

Feinberg and Robert, M., 2000, The Role of International Discipline in Three Developing Economies: Exchange Rate Effects on Domestic Prices in Colobia, Korea and Morocco, Review of International Economies, 8, pp.126-133.

Fernardo N.de Oliveira (2009), Effects of Monetary Policy on Firms in Brazil: An Empirical Analysis of the Balance Sheet Channel, Brazilian Review of Econometrics v. 29, no 2, pp. 171-204 November 2009

FiorellaDeFiore (2009), Monetary and The financing of firms, working paper.

Foot, Michael (2003), What is "Financial Stability" and How Do We Get It?, The Roy Bridge Memorial Lecture (United Kingdom: Financial Services Authority)

Ghei, Nita, Pritchett, and Lant (eds.), (1999), The Three Pessimisms: Real Exchange Rates and Trade Flows in Developing Countries, New York: Oxford University Press.

Ghei, Nita, Pritchett, and Lant (eds.), 1999, The Three Pessimisms: Real Exchange Rates and Trade Flows in Developing Countries, New York: Oxford University Press.

Glenn Boyle, Corporate investment policy: What is the cost of capital, University of Otago

Goujon, M., (2006), Fighting Inflation in a Dollarized Economy: The case of Vietnam, Journal of Comparative Economics, 34, pp.564581.

Goujon, M., 2006, Fighting Inflation in a Dollarized Economy: The case of Vietnam, Journal of Comparative Economics, 34, pp.564-581.

Gregory E. Elliehausen \& John D. Wolken, (1990), Banking markets and the use of financial services by small and medium- sized businesses, Federal Reserve Bulletin, Board of Governors of the Federal Reserve System (U.S.), issue Oct, pages 801-817.

Jean-Bernard Chatelain \& Andre Tiomo, (2003), Monetary Policy and Corporate Investment in France, Université Paris1 PanthéonSorbonne (Post-Print and Working Papers) halshs-00112523, HAL.

Kashyap, Anil K, Jeremy C. Stein and David W. Wilcox, (1993), Monetary Policy and Credit Conditions: Evidence from the Composition of External Finance, American Economic Review, March 1993, 83: 78-98

Kathryn L. DeWenter and Paul H. Malatesta, (2001), State-Owned and Privately Owned Firms: An Empirical Analysis of Profitability, Leverage, and Labor Intensity, American Economic Review Vol. 91, No. 1. 
Leonard I. Nakamura \& William W. Lang, (1995), New directions in information and screening in real estate finance, Working Papers 9517, Federal Reserve Bank of Philadelphia.

Mark Gertler and Simon Gilchrist, (1994), Monetary Policy, Business Cycles, and the Behavior of Small Manufacturing Firms, Quarterly Journal of Economics, vol. 109, no. 2, pp. 309-340.

Mark Gertler, Simon Gilchrist, (1994), "Monetary policy, Business cycle and the behavior of small manufacturing firms".

Michael C. Jensen and William H. Meckling, (1976), Theory of the Firm: Managerial Behavior, Agency Costs and Ownership Structure, Journal of Financial Economics, October, 1976, V. 3, No. 4, pp. 305-360.

Mishkin Frederic S. (2013), The Economics of money, banking, and financial markets - 10thedition

Modigliani, F.; Miller, M. (1958). "The Cost of Capital, Corporation Finance and the Theory of Investment". American Economic Review. 48 (3): 261-297.

Modigliani, F.; Miller, M. (1963). "Corporate income taxes and the cost of capital: a correction". American Economic Review. 53 (3): 433443.

Mohsin, Hasan M \& Ashraf, Muhammad Shahzad, (2011), Monetary policy restriction and dividend behavior of Pakistani firms: an empirical analysis, MPRA Paper 34052, University Library of Munich, Germany, revised Oct 2011.

Moron and Winkelried (2005), Monetary policy rules for financially vulnerable economies, Journal of Development Economics, 2005, Vol 76

Muhammad Ashraf (2011), "Monetary restriction and dividend behavior of Pakistani firms: An empirical analysis", Working paper, Shaheed Zulfikar Ali Bhutto Institute of Science and Technology, Islamabad, Pakistan. Colombia University

Myers, Stewart C. and Majluf, Nicholas S. (1984), Corporate financing and investment decisions when firms have information that investors do not have, Journal of Financial Economics 13 (2): 187-221. doi:10.1016/0304-405X(84)90023-0

Natalia Zaderey (2003), Monetary transmission in Ukraine: is there a broad credit channel?, Master of Arts in Economics, National University of "Kyiv-Mohyla Academy" Economics Education and Research Consortium Master's Program in Economics

Nguyen Xuan Thang (2014), Working paper: applying Taylor principals in determining target interest rate, Banking Academy.

Nobuhiro Kiyotaki and John Moore (1997), Credit Cycles, Journal of Political Economy, Vol. 105, No. 2 (April 1997), pp. 211-248

Oliner, Stephen D. and Glenn D. Rudebusch. (1996), Monetary Po I i cy and Credit Conditions: Evidence from the Composition of External Finance: Comment, Manuscript, forthcoming A m erican Economic Review.

PatrickBolton (2006), "Corporate Finance and Monetary Transmission Mechanism", Working paper, Colombia University

Rajan, R., (1992), Insiders and Outsiders: The Choice between Informed and Arm's-Length Debt, Journal of Finance 47: 1367-1400

Romer, Christina D., and David H. Romer, (1990), New Evidence on the Monetary Transmission Mechanism, Brookings Papers on Economic Activity 1, pp. 149-213

Sarat Dhal (2011), Industry Effects of Monetary Transmission Mechanism in India: An Empirical Analysis of Use-based Industries, Reserve Bank of India Occasional Papers 32, 39-79

Sriphayak, A and P Vongsinsirikul (2006), Asset prices and monetary policy transmission in Thailand, BIS Annual Autumn Central Bank Economists' Meeting 2006: Understanding asset prices: determinants and policy implications, October.

Stiglitz, J.E. and Weiss, A., (1981), Credit rationing in markets with imperfect information, American Economic Review, Vol. 71 (3), pp. 393-410

Takashi Nagahata \& Toshitaka Sekine, (2002), The Effects of Monetary Policy on Firm Investment after the Collapse of the Asset Price Bubble: An Investigation Using Japanese Micro Data, Bank of Japan Working Paper Series Research and Statistics D, Bank of Japan.

Takeo Hoshi \& Anil Kashyap \& David Scharfstein, (1993), The Choice Between Public and Private Debt: An Analysis of PostDeregulation Corporate Financing in Japan, NBER Working Papers 4421, National Bureau of Economic Research, Inc.

Thomas F. Cooley (1999), "Monetary Policy and The Financial Decisions of Firms", Working paper, NSF Grant SBR.

Thomas F.Cooley, Vincenzo Quadrini, (1999) "Monetary Policy and the financial decision of Firms".

Thomsen, Steen, and Pedersen, Torben (1996), Nationality and Ownership Structures: The 100 Largest Companies in Six European Nations, Academic Journal Article, Management International Review

Tian Chaterlain (2003), Working paper: Monetary policy and corporate investment in France, Cambridge university press.

Tobin, James. (1969), A General Equilibrium Approach to Monetary Theory, Journal of Money, Credit, and Banking, February, 1(1), pp. $15-2$

VCCI (2008), Vietnam's enterprise annual report, Vietnam Enterprise Association

VCCI (2014), Vietnam's enterprise annual report, Vietnam Enterprise Association

Website:www.data.worldbank.org; sbv.gov.vn; imf.org; gso.gov.vn, UBGSTCQG...

Yeyati, E.L. và Sturzenegger, F. (2010), Monetary and Exchange Rate Policies, Handbook of Development Economics, Vol. 5, Chương 64 , trang 4215-4281

Zaderey, N. (2003). Monetary Transmission in Ukraine: Is There a Broad Credit Channel? Economics Education and Research Consortium. 
ISSN 2039-2117 (online)

ISSN 2039-9340 (print)
Mediterranean Journal of Social Sciences MCSER Publishing, Rome-Italy
Vol 7 No 6 November 2016 